PF 2019 (LXXIII): 521-543

\author{
AGNIESZKA PIOTROWSKA \\ Instytut Języka Polskiego \\ Uniwersytet Warszawski \\ ul. Krakowskie Przedmieście 24/26 \\ 00-927 Warszawa \\ tel. (+22) 5521021 \\ e-mail: a.piotrowska@uw.edu.pl
}

\title{
WTÓRNE ZNACZENIA WYRAZÓW \\ PERCEPCYJNYCH ZMYSŁOWYCH \\ (ZMYSŁ POWONIENIA, DOTYKU I SMAKU) \\ - PRÓBA REKONESANSU
}

SŁOWA KLUCZOWE: percepcja, węch, dotyk, smak, znaczenie prymarne, znaczenie wtórne

KEYWORDS: perception, touch, smell, taste, primary meaning, secondary meaning

\author{
SECONDARY MEANINGS OF SENSORY WORDS \\ (OLFACTORY, TACTILE AND GUSTATORY) - PRELIMINARIES
}

\begin{abstract}
In this paper we discuss the secondary meanings of various verbs that are related to three senses: touch, smell and taste. We present a detiled review of the topic in versatile languages, mainly but by no means solely indoeuropean, and discuss the issue from the perspective of Polish language. Large number of secondary meanings of verbs that describe the three senses addressed in this paper is, in the majority of considered languages, basically the same. This suggest that similar semantic processes occure in such different languages as Aborigenal, Papuan, Bask, Polish, English or Spanish. As many of that laguages are not related with the others, and have no common acestors known, the only explanation of found similarities have to be based on biology, and perceptual and sensitive processes that are responsible for the similarities are probably common to all humans.
\end{abstract}




\section{Wprowadzenie}

W niniejszym artykule chciałabym dokonać przeglądu wtórnych znaczeń czasowników prymarnie percepcyjnych węchowych, dotykowych i smakowych, posiłkując się ustaleniami Iraide Ibarretxe-Antuñano dla wybranych angielskich, hiszpańskich i baskijskich verbów. Autorka ta bada kierunki przeobrażeń semantycznych, pyta o przyczyny polisemii i sposób jej powstawania oraz funkcjonowania w niespokrewnionych ze sobą językach. Zastanawia się też nad możliwą uniwersalnością części zmian znaczeniowych, a swoje rozważania uzupełnia informacjami etymologicznymi, gdyż te same mechanizmy, które wyjaśniają wieloznaczność współczesnego słownictwa percepcyjnego, można odnieść do jego historycznych treści (Ibarretxe-Antuñano 1999b, s. 105). Wyniki badań I. Ibarretxe-Antuñano zestawiam ze spostrzeżeniami Anny Pajdzińskiej, Anny Wierzbickiej, Renaty Bronikowskiej i Barbary Mitrengi oraz uzupełniam własnymi przykładami. Język polski jako niespokrewniony z żadnym z języków uwzględnionych przez Ibarretxe-Antuñano i nie pozostający przez dłuższy czas ${ }^{1}$ pod wpływem żadnego $\mathrm{z}$ nich umożliwia sprawdzenie, czy opisane zmiany znaczeniowe można uznać za - w jakimś stopniu - uniwersalne. Ograniczenie do trzech, tzw. niższych, zmysłów ma uzasadnienie praktyczne - są to rozmiary artykułu - oraz merytoryczne.

Węch, smak i dotyk często są omawiane łącznie jako tzw. zmysły bliższe, wymagające niewielkiego dystansu między perceptorem a bodźcem, i z tego powodu uznaje się je za mniej obiektywne od wzroku i słuchu. Znajdują się one niżej od dwóch ostatnich w językowej hierarchii zmysłów ${ }^{2}$ sporządzonej na podstawie analizy współczesnych ${ }^{3}$ czasowników percepcyjnych z różnych niepowiązanych genetycznie ani kulturowo języków naturalnych, a w polszczyźnie do mówienia o percepcji węchowej, dotykowej i smakowej używa się czasownika czuć

1 Język angielski zaczął oddziaływać na polszczyznę w dobie nowopolskiej, ale do 1989 roku jego wpływ nie był znaczący, przynajmniej jeśli brać pod uwagę leksykę percepcyjną.

2 Na szczycie hierarchii zmysłów Åke Viberg umieścił wzrok, następnie słuch, w dalszej kolejności: dotyk, węch i smak, przy czym trudno stwierdzić, czy dwa ostatnie zmysły pojawiają się w każdym języku w tej właśnie kolejności (Viberg 1984, s. 136; zob. Piotrowska 2018). Różnice w hierarchiach dotyczą pozycji dotyku i smaku (por. Pallasmaa 2012, s. 22 i 49). Inny sposób zhierarchizowania zmysłów należy współcześnie do wyjątkowych i charakteryzuje języki pozostające poza wpływem kultury okcydentalnej, np. niektóre języki Indian obu Ameryk, Aborygenów, mieszkańców Papui-Nowej Gwinei i Afryki (zob. Ibarretxe-Antuñano 2002, s. 25; Wierzbicka 2006, s. 231-234).

3 Zazwyczaj Viberg nie zestawia treści czasowników percepcyjnych z drugiej połowy XX wieku z ich poświadczeniami z wcześniejszych okresów historycznych, nie uwzględnia też różnic między językami literackimi a ich gwarami. 
(por. Chojak 2007, s. 80-83) ${ }^{4}$. Åke Viberg zwrócił uwagę, że nie tylko podział na pięć $c^{5}$ zmysłów trzeba uznać za konwencjonalny (por. Mitrenga 2014, s. 24-25; Wierzbicka 2006, s. 103), lecz tak samo potraktować należy przypisywanie każdemu z nich odrębnych wykładników leksykalnych.

Polisemia zazwyczaj jest umotywowana etymologicznie, wykształca się i rozpowszechnia w danym języku, można ją tłumaczyć zarówno zmianami wewnątrz-, jak i zewnątrzjęzykowymi. Przekształcenia znaczeniowe mogą być właściwe grupie języków spokrewnionych, pozostających w tym samym kręgu kulturowym lub ograniczać się do jednego języka. Kierunek zmian w wypadku słownictwa percepcyjnego przebiega od konkretnych bodźców sensorycznych odbieranych za pomocą zmysłów do złożonych działań fizycznych oraz procesów umysłowych i emocjonalnych, gdyż doświadczając świata, człowiek nie oddziela czynników fizycznych, intelektualnych i emocjonalnych, ale podlega im całościowo i w taki sposób odpowiada na te doznania (Johnson 2015, s. 90 i n.). W języku odzwierciedla się to m.in. tak, że wtórne treści polisemów percepcyjnych można objaśniać nienaukową wiedzą o świecie każdego z nas i naiwnym sposobem myślenia. Doświadczenia zmysłowe, towarzyszące im emocje oraz - często trudne do ujęcia i rozgraniczenia - myśli pojawiają się na bardzo wczesnym etapie życia każdego z nas i mają swoją biologiczną podstawę (por. Ibarretxe-Antuñano 1999b, s. 29).

Przeobrażenia konkretnych znaczeń zmysłowych w abstrakcyjne zostały stosunkowo dobrze opisane w językach indoeuropejskich dla wzroku ${ }^{6}$, nieco słabiej dla pozostałych zmysłów (por. Sweetser 1990, Pajdzińska 1996, Kővecses 2001, Wierzbicka 2006; Ibarretxe-Antuñano 1999b, s. 29) i języków z innych rodzin, przykładowo: hebrajskiego (Termińska 2015, s. 71-88), baskijskiego (IbarretxeAntuñano 1999b) czy języków ludów zamieszkujących Papuę-Nową Gwineę

4 Treść percepcyjna słuchowa czuć ogranicza się do dawnej polszczyzny i gwar. W staropolszczyźnie jest dyskusyjna, natomiast w XVI w. została poświadczona przez Jana Kochanowskiego. Występowała aż do połowy XVIII wieku, ale można ją uzać za regionalną, zważywszy na źródła, z których ekscerpowane są dane do E SXVII-XVIII.

5 Hans Kurath, pisząc o zmyśle dotyku, włącza do rozważań odczuwanie ciężaru, nacisku (ang. muscular sensation) (Kurath 1921, s. 43), gdyż jest ono nierozerwalnie z nim związane, mimo że w analizach aktywnego dotykania często się ten aspekt pomija.

6 Juhani Pallasmaa upatruje początków myślenia o dominującej roli wzroku i łączenia go z wiedzą już w filozofii greckiej, która została przeniesiona do średniowiecza przez Tomasza z Akwinu (por. Pallasmaa 2012, s. 21-22) i rozwinięta w renesansie, od czasów oświecenia mówi się o hegemonii wzroku i dominującej roli światła w poznaniu (por. Kranowitz 2012, s. 140).

7 Np. lud Ommura używa czasownika iero na oddanie treści 'rozumieć' i 'słyszeć dźwięki', a lud Gahuku-Gama ma czasownik gelenove, oznaczający zarówno 'myśleć', 'wiedzieć', jak i 'słyszeć' (por. Wierzbicka 2006, s. 231). 
i Australię ${ }^{8}$ (por. Wierzbicka 2006, s. 231). Do takich prac trudniej dotrzeć ze względu na dostępność publikacji i ich język.

Poniżej scharakteryzuję kolejno zmysły - węch, dotyk i smak - i postaram się ukazać, jak wyrazy o pierwotnym znaczeniu percepcyjnym ewoluują semantycznie w polszczyźnie, języku angielskim, hiszpańskim i baskijskim. Ponieważ przykłady pochodzą z różnych publikacji i słowników, podaję ich lokalizację. Jeśli to możliwe, przywołuję dawne i współczesne treści czasownika czuć lub jego wyrazów pochodnych. Ze względu na rozmiary artykułu i zarysowany temat pomijam podział czasowników na stanowe, czynnościowe i opisowe ${ }^{9}$, chociaż szczegółowsza analiza by tego wymagała (por. Chojak 2007, Grzegorczykowa 2012).

\section{Węch}

W językach angielskim, hiszpańskim i baskijskim czasowniki odnoszące się do odbierania bodźców za pomocą węchu mają metaforyczne znaczenia: 'zgadywać, 'podejrzewać' i 'śledzić, badać' (por. Ibarretxe 1996, s. 642), które łączy pojawianie się w kontekście 1) informacji o czymś negatywnym dla podmiotu (por. Ibarretxe 1996, s. 631) oraz 2) mniejsza niż w wypadku czasowników etymologicznie związanych ze wzrokiem i słuchem weryfikowalność wiedzy podmiotu.

Pierwszą z cech łatwo wytłumaczyć uwarunkowaniami biologicznymi - przy oddychaniu nie sposób uniknąć wdychania przykrych zapachów, a zatykanie nosa nie sprawia, by dało się całkowicie uniknąć nieprzyjemnej dla perceptora woni. Renata Grzegorczykowa negatywne nacechowanie treści wywodzących się od percepcji węchowej wiąże z wysyłaniem bodźca (pachnieć, śmierdzieć, cuchnać, ? wonieć [oznaczenie za R. Grzegorczykową - A.E.P.] i ang. it smells) i celowym poszukiwaniem go (wąchać (coś), węszyć, ang. to smell) (por. Grzegorczykowa 2012, s. 162 i 167), przykładowo: To pachnie kryminłem, Zwąchali się i Węszyć wszędzie intryge (Grzegorczykowa 2012, s. 167). Autorka przypuszcza, że wtórne odniesienie wyrazów węchowych do działań wątpliwych moralnie może wynikać z łączenia prymarnego znaczenia słów śmierdzieć, smród i smrodek nazywających wydawanie nieprzyjemnych zapachów ze zgnilizną i psuciem się obiektu, co widać w wypowiedzeniach: Śmierdząca sprawa, Raport na milé śmierdzi kantem

\footnotetext{
$8 \quad$ Ilustruje to polisemiczny czasownik kulini, który w języku yankunytjatjara oznacza zarówno 'słyszeć', jak i 'myśleć' (Wierzbicka 2006, s. 232). Więcej przykładów znajduje się na kolejnych stronach pracy Anny Wierzbickiej (2006, s. 234 i n.).

9 Tak jak w większości prac dotyczących wtórnych treści percepcyjnych, co znacznie upraszcza analizę. Przykładowo ang. czasownik to smell oznacza zarówno 'czuć zapach', 'wąchać', jak i 'pachnieć', więc jego wtórne znaczenia są motywowane przez wszystkie te sensy i część badaczy w ten sposób traktuje języki, w których czasownik percepcyjny węchowy nie jest wieloznaczny.
} 
(Grzegorczykowa 2012, s. 168). Sens związany z zachowaniami ocenianymi jako moralnie negatywne (konkretne znaczenie - psucie się, i przenośne - korupcja) wskazuje też Ibarretxe jako charakterystyczny dla języka Basków ${ }^{10}$ (zob. Aneks, tabela 3.). Na zastanowienie zasługuje spostrzeżenie Grzegorczykowej odnoszące się do sytuacji, gdy człowiek uczciwy i niewinny zauważa, że tworzy się wokół niego "gęsta” atmosfera, a ludzie odsuwają się od niego, jakby wyczuwali niewidoczny, ale nieprzyjemny zapach ${ }^{11}$.

Mniejszą niż w wypadku wzroku czy słuchu weryfikowalność wiedzy podmiotu w metaforycznie użytych czasownikach percepcji węchowej analizuje Ibarretxe-Antuñano na przykładzie angielskich zdań złożonych, w których orzeczeniem w wypowiedzeniu nadrzędnym jest czasownik o podstawowym znaczeniu percepcyjnym zmysłowym:

a) I saw that there was going to be trouble - wzrokowym

b) I heard that there was going to be trouble - słuchowym

c) I smelt that there was going to be trouble - i węchowym (za: IbarretxeAntuñano 2008, s. 22).

Każdy z nich został użyty w powyższych kontekstach w sensie mentalnym, aby wyrazić stopień pewności wiedzy podmiotu. W zdaniu a) czasownik see można sparafrazować za pomocą 'to know' ('wiedzieć'), w zdaniu b) najbliższy semantycznie hear jest 'to be told' ('dowiedzieć się, być poinformowanym'), w c) smell można objaśnić za pomocą 'to quess, to suspect' ('zgadywać, domyślać się; podejrzewać, czuć' ${ }^{12}$ ). Język Basków, hiszpański, a także polszczyzna zaświadczają zbliżone różnice znaczeniowe:

a) Widzę, że zanosi się na kłopoty.

b) Słyszę, że zanosi się na kłopoty.

c) Czuję, że $e^{13}$ zanosi się na kłopoty.,

10 Spośród wyróżnionych przez nią treści nie znajduje potwierdzenia w polszczyźnie tylko wtórny sens czasownika percepcyjnego węchowego sprowadzający się do okazywania komuś wzgardy (przez pociąganie nosem czy prychanie), cechujący tylko język baskijski.

${ }_{11}$ Podaje ona następujące konteksty: Ich spojrzenia mówiły mi, że jakiśsmród się wokót mnie robi: mam wrogów, $W$ parę miesięcy później człowieka uniewinniono, ale smrodek pozostał (Grzegorczykowa 2012, s. 168).

${ }_{12}$ To znaczenie sekundarne odnosi się do konkretnego sensu zdarzeniowego ang. to smell w sytuacji odbioru bodźca bez udziału woli człowieka, dlatego oddaję je w tłumaczeniu za pomocą czasownika czuć.

13 Charakterystyki struktur ze zdaniem podrzędnym wprowadzanym przez spójnik $\dot{z} e$ można znaleźć w pracach Magdaleny Danielewiczowej (np. Danielewiczowa 2000a, 2000b i 2002). Czasownik $c z u c ́$ w konstrukcji wymagającej biernika lub prawostronnie włączający zdanie podrzędne (czuć, $\dot{z} e_{-}$) uznaje ona za mentalny i prospektywny (zob. Danielewiczowa 1998, s. $119-129 ; 2000$ a, s. $275-288 ; 2000$ b, s. 243; 2002, s. 201-205). 
co pozwala przyjąć, iż niuanse semantyczne wynikają z powiązania tych verbów z poszczególnymi zmysłami ${ }^{14}$. Pewność wiedzy podmiotu zmniejsza się wraz ze „schodzeniem” w hierarchii zmysłów od wzroku przez słuch do węchu (IbarretxeAntuñano 2002, s. 21; Viberg 1984), co ma uzasadnienie w rzeczywistości pozajęzykowej - powonienie uznaje się za najmniej zintelektualizowany ze zmysłów z uwagi na konieczną bliskość podmiotu i obiektu emitującego zapach (Czerniawska, Czerniawska 2005, s. 105). Ludzie są też w różnym stopniu wrażliwi na zapachy, które nie pozostawiają wszak śladów. Te właściwości pozajęzykowe uaktualniają się we wtórnych treściach ang. smell i pol. czuć: umiejętności przewidywania przez podmiot na podstawie niejasnych przesłanek oraz orientacji w sytuacji nieoczywistego (dla każdego) zagrożenia. Komponenty znaczeniowe czuć określa się u ludzi jako intuicyjne, a u zwierząt - instynktowne.

W polszczyźnie wymienione cechy uwidaczniają się m.in. we sfrazeologizowanych zwrotach z wyrazem nos jako nazwą organu (np. mieć dobrego nosa, robić coś na nosa, wyczuć pismo nosem), który przenośnie oznacza 'intuicję,' 'zdolność przewidywania, zdolność trafnego wyboru, intuicyjnego rozumienia sytuacji, podejmowania decyzji opartej nie na rozumowaniu, ale na wyczuciu' (Grzegorczykowa 2012, s. 167) ${ }^{15}$. Anna Pajdzińska przy analizie wtórnych treści słownictwa $\mathrm{z}$ pola węchu uwypukla komponenty mentalne - wnioskowanie o czymś i dostrzeganie związków przyczynowo-skutkowych, które ujmuje przede wszystkim jako instynktowne, oraz nacechowanie negatywne: 'ktoś domyśla się czegoś złego, przewiduje to’: (coś) (komuś) pachniel śmierdzi (czymś); (coś) (gdzieś) (komuś) śmierdzi; (ktoś) (gdzieś) węszy; (ktoś) (coś) wyniuchał (zob. Pajdzińska 1996, s. 127-128). Tę ostatnią cechę omawianych leksemów potwierdzają ustalenia Barbary Bartnickiej poczynione na przykładzie twórczości Stefana Żeromskiego: wtórne znaczenia leksyki węchowej często odnoszą się do sytuacji z przeszłości, które budzą odrazę i silne emocje negatywne u podmiotu (por. Bartnicka 2007, s. 14). Trudno to ukazać przy analizie leksyki, jest natomiast widoczne przy charakterystyce szerszych kontekstów i znajduje potwierdzenie w biologii: zapachy są rozpoznawne w układzie limbicznym, bardzo starej części naszego mózgu, która odpowiada za emocje, seksualność, pamięć i kreatywność (por. Kranowitz

\footnotetext{
${ }_{14}$ W polskim zdaniu a) wiedza podmiotu jest niekwestionowana i ma oparcie w faktach, w zdaniu b) podmiot wnioskuje na podstawie tego, czego się dowiedział/ co usłyszał, o przyszłości, natomiast w zdaniu c) trudno przesądzać o wiedzy podmiotu, jest to raczej jego przekonanie wynikające z intuicji i wcześniejszych doświadczeń. Ostatnie zdanie można odnieść do nieuświadamianej przez podmiot pamięci, dzięki której przeczuwa przyszłe wydarzenia, więc może - dzięki temu - uniknąć niebezpieczeństwa.

15 Trudno powiedzieć, jaką treść w tym wypadku należy uznać za podstawową - stan czy czynność, co przekłada się chociażby na niezależne od woli podmiotu lub świadome i celowe
} działanie. 
2015, s. 204), z tego powodu błyskawicznie potrafią przywołać wspomnienia' ${ }^{16}$. Znaczenie 'wyczuwać coś, przeczuwać coś (instynktem?)' czasownika czuć poświadczane od XVI wieku w kolejnych stuleciach ustabilizowało się i uwidoczniło w derywatach prefiksalnych przeczuć i wyczuć (oraz pochodnych od nich - przeczuwać, przeczucie; wyczuwać i wyczucie), charakteryzuje ono także kostrukcję czuć, że_. Gwoli ścisłości należy dodać, że czuć jest notowany jako czasownik percepcyjny węchowy od początków polszczyny historycznej (por. SStp i Brückner 1970, s. 81).

Ibarretxe-Antuñano za właściwości składające się na odbiór i rozpoznanie bodźca zapachowego uznaje: bliskość $(+)^{17}$, uwewnętrznienie $(+)$, dobrowolność $(-/+)^{18}$, wykrywanie (ang. detection) $(+)$, identyfikację $(+/-)^{19}$, subiektywność $(+)^{20}$ i emocjonalność $(+)$, niewystępującą z taką intensywnością w żadnym innym rodzaju percepcji zmysłowej (Ibarretxe-Antuñano 1999a, s. 37). Z jej spostrzeżeń wynika, że uwarunkowania biologiczne lub kulturowe są przenoszone naturalnie i w miarę konsekwentnie na płaszczyznę abstrakcyjną za pomocą metafor (zob. Ibarretxe-Antuñano 1998, s. 202), chociaż w znaczeniach wtórnych realizuje się tylko część wymienionych właściwości i nie sposób przewidzieć, który z czynników zaktualizuje się w danej treści (por. Ibarretxe-Antuñano 1999b, s. 168)²1.

16 Co w warstwie językowej może potwierdzać spectrum znaczeniowe hebrajskiego rdzenia RW(aw)H(et), od 'być szerokim, rozprzestrzeniać się' poczynając, przez 'wiać, dąć, oddychać, tchnąć', na formach kauzatywnych kończąc - 'być wonnym, pachnieć' i 'wąchać, wdychać zapach, delektować się nim’ oraz fundowanych przez ten rdzeń nominach, przede wszystkim RUaH, łączącym treści 'powiew, podmuch', 'dech, tchnienie', 'wiatr', 'oddychanie, dusza, duch', 'życie, wola' i 'umysł, rozum, sposób myślenia'. Zwraca na to uwagę Termińska, podsumowując rozważania: „Nierzadko zapach nie jest ściśle określony, a «woń» metaforycznie oznacza wspomnienie i pamięć, wyobrażenie i oczekiwanie” (Termińska 2015, s. 85).

17 Plus oznacza pojawienie się cechy, plus/ minus występowanie sytuacji, które mogą być dyskusyjne.

18 Dobrowolność (+/-) odnosi się do ang. smell, który jest używany do percepcji czynnej i biernej. Bierne odbieranie zapachów jest niezależne od woli perceptora, gdyż oddycha on nawet wtedy, gdy jest tego nieświadomy. Zwraca zaś uwagę na zapach, kiedy go rozpoznaje lub ocenia w kategoriach hedonistycznych (Ibarretxe-Antuñano 1999b, s. 139-140 i 146).

19 Fakt, że kojarzymy jakiś zapach i łączymy go ze wspomnieniem lub emocją nie oznacza, że umiemy go nazwać lub podać jego źródła. Z powodu trudności w nazywaniu nawet znanych zapachów pojawiają się przy dookreślaniu woni przymiotniki genetycznie związane z innymi zmysłami - dotykiem (np. ostry) i smakiem (np. mdły, gorzki) (zob. Ibarretxe-Antuñano 1999b, s. 36).

20 Aby zaistniała dodatnia cecha subiektywności (+), muszą pojawić się dwa inne komponenty z wartością dodatnią: bliskość i uwewnętrznienie (por. Ibarretxe-Antuñano 1999b, s. 156).

21 Ibarretxe-Antuñano ilustruje tę zależność na przykładzie sensu 'śledzić kogoś' w ang. czasowniku smell (por. pol. węszyć za kimś, czymś, wywąchać lub zwąchać kogoś, coś), który - wskutek uabstrakcyjnienia - przekształcił się w treść 'badać kogoś, coś'. W obu tych znaczeniach zrealizowały się tylko dwa z wymienionych czynników: wykrywanie (+) i dobrowolność (+) (Ibarretxe-Antuñano 1999a, s. 40). Zrozumienie metafory zależy zatem od zrozumienia jej konkretnej podstawy znaczeniowej i doświadczenia tkwiącego u źródła konceptualizacji. 


\subsection{Węch $v$. słuch i inne zmysły}

Dostrzeżony przez Viberga związek doświadczeń percepcyjnych słuchowych i węchowych wynika $z$ braku kontaktu perceptora $\mathrm{z}$ obiektem emitującym bodziec $^{22}$, koniecznego w wypadku smaku i dotyku. Bliskość doznań słuchowych i węchowych potęguje wrażenie wypełnienia perceptora przez bodziec (dźwięk czy zapach), który wchodzi do jego wnętrza, oraz z faktu, że najsilniej odbiera się te wrażenia w ciemności, gdy wzrok jest niejako „wyłączony”. Językową bliskość treści słuchowych i węchowych zaświadczają niespokrewnione ze sobą i oddalone od siebie terytorialnie języki Afryki (bez części północnej i saharyjskiej), język Basków (por. Ibarretxe-Antuñano 1999b, s. 67) oraz - nieco uogólniając - wschodnia słowiańszczyzna ${ }^{23}$. Polskie dialekty także potwierdzają ten związek na przykładzie czasownika czuć, który w języku ogólnym odnosi się m.in. do percepcji węchowej, smakowej i dotykowej, ale w wielu gwarach uwzględnia też słuch $^{24}$. Język słowacki zaświadcza znaczenie 'słyszeć' w čut' i pochodnych od niego czasownikach prefigowanych (por. Piotrowska 2018, s. 447 i n.; OLA, t. 9, mapa 61). Za pomocą jednego czasownika o treści percepcyjnej słuchowej wyrażane są sensy związane ze zmysłem węchu, dotyku i smaku w językach bantu i hausa ${ }^{25}$, a poza Afryką - częściowo (!) w tureckim i być może we włoskim, co wskazuje na zawężanie jego pierwotnej treści do sensów znajdujących się coraz niżej w hierarchii zmysłów (zob. Viberg 1984, s. 141-142).

\section{Dotyk}

Zmysł dotyku jeszcze w drugiej połowie XIX wieku nazywano zmysłem dotykania, uwypuklając w ten sposób, że treściowo najbliższy jest czynności. Taka sama sytuacja jest charakterystyczna dla hebrajszczyzny, czym Kamilla Termińska

22 R. Grzegorczykowa upatruje w ich oddaleniu przyczynę wykształcenia się tzw. czuć nieosobowego, w którym perceptor może być nieokreślony, jak w zdaniu $W$ tej zupie czuć paprykę, jeśli nie jest nim nadawca (por. Grzegorczykowa 2012, s. 165-166).

23 Viberg włącza tu także język rosyjski (Viberg 1984, s. 142).

24 Sens 'doznawać wrażeń słuchowych; słyszeć' czasownika czuć rejestrują Słownik gwar polskich pod kierunkiem J. Reichana (1994-1998, V s. 204-205) i Słownik gwar polskich J. Karłowicza (1900, I s. 289) na podstawie materiałów z Wielkopolski i Pomorza oraz (mniej licznie) województw: małopolskiego, podkarpackiego, śląskiego (przede wszystkim w okolicach Cieszyna), lubelskiego i podlaskiego, a także u Polaków mieszkających poza krajem - w Cieszynie Czeskim, na północy Słowacji - w Czacy i na Orawie, na Ukrainie - w Tarnopolu i Drohobyczu. Odniesienie do percepcji słuchowej może charakteryzować wyrazy pochodne, np. czujny w niektórych gwarach małopolskich oznacza 'mający dobry węch i słuch' (o psie) (Kucała 1957, s. 75).

25 Występują one w językach wielu państw w Afryce wschodniej (Kenia i Uganda), południowej (Zambia i Botswana) oraz zachodniej (Nigeria) (za: Viberg 1984, s. 142). 
tłumaczy fakt, iż rdzenie przynależne w hebrajskim temu zmysłowi nie odnoszą się do sfery mentalnej (Termińska 2015, s. 84-86).

Przedstawiciele różnych gałęzi nauk przyrodniczych piszą o zmyśle czucia, aby uwzględnić szeroki zakres doświadczeń łączących się z różnorakim percypowaniem powierzchnią całej skóry ${ }^{26}$. Są to doznania wysoce zsubiektywizowane, najbardziej spośród wszystkich sensualnych (Sweetser 1990). Z tego powodu leksyka określająca ten typ percepcji sekundarnie odnosi się do emocji i uczuć, co dostrzeżono już w pierwszej połowie XX wieku i uzasadniano ich psychosomatyczną naturą (Kurath 1921; Buck 1949, s. 1062). Wówczas jednak nie badano tej relacji, dopiero Sweetser dostrzega w takiej ewolucji znaczeniowej (względnie) uporządkowany system koncentrujący się wokół metafory UMYSŁ JAKO CIAŁO (ang. MIND-AS-BODY) (por. Lakoff, Johnson 1980).

Ewelina Ładziak daje przykłady metaforycznych rozszerzeń pierwotnych czasowników percepcji dotykowej na sferę emocji - m.in. wartościowany pozytywnie czasownik głaskać (coś głaszcze nasza ambicję, dumę, próżność 'pochlebia nam, sprawia przyjemność) i negatywnie - szczypać, np. uszczypliwe uwagi (por. Ładziak 2012, s. 112-116), który konotuje ból fizyczny, a w użyciach przenośnych - emocjonalny (por. Kurath 1921, s. 43). Cechą dotyku jest bowiem nie tylko brak dystansu między podmiotem a przedmiotem, ale także fakt, iż kontakt ten nie musi być przyjemny dla perceptora, do czego nawiązują metaforyczne użycia wyrazów percepcyjnych dotykowych, np. (kogoś) dotknął los, choroba, nieszczęście; (coś) dotknięte grzybem, rdzą; dotkliwy cios dla (kogoś); dotkliwy wiatr, chłód, mróz. Anna Pajdzińska wtórne treści słownictwa percepcyjnego dotykowego odnosi do wiedzy będącej skutkiem kontaktu (dotyk jako pewność doświadczenia), początku jakiegoś działania, np. dotknąć się (czegoś); dotknąć (czegoś), np. sprawy, tematu, lub relacji, jak w połączeniu (coś) dotyczy (kogoś, czegoś) (zob. Pajdzińska 1996, s. 124).

Czasowniki dotykowe rozpatruje I. Ibarretxe-Antuñano na przykładzie ang. touch, hiszp. tocar i bask. ukitu (pol. dotknąć, dotykać), które poza konkretnym znaczeniem każdorazowo zaświadczają (wskutek przesunięć dominanty znaczeniowej, uabstrakcyjnienia lub zmian metonimicznych) treści 'spróbować jedzenia/ picia', 'oddziałać, wywrzeć wpływ na kogoś, coś (fizycznie i psychicznie)', 'dojść do czegoś, osiągnąć coš²7, 'mieć z kimś, czymś do czynienia' (por. Aneks, tabela 3.; Ibarretxe-Antuñano bd, s. 240), co tłumaczy sposobem

\footnotetext{
${ }^{26}$ Konsekwentnie o zmyśle czucia pisze Bożydar Kaczmarek, podkreślający jego rolę przy metaforach wyrażających stany emocjonalne (Kaczmarek 2010, s. 383-384).

27 Ibarretxe-Antuñano podkreśla obecną w tym znaczeniu graniczność przestrzenną i/ lub czasową. Hebr. rdzeń NG', mający m.in. sens percepcyjny dotykowy, uwypukla informację o powierzchni jakiegoś przedmiotu lub ludzkiego ciała (por. Termińska 2015, s. 86-87), choć ten komponent znaczeniowy realizuje się też w innych treściach i użyciach wyrazów z tym rdzeniem.
} 
konceptualizacji doznań fizycznych oraz wspólnotą kulturową ${ }^{28}$. Dwa pierwsze spośród wymienionych znaczeń można odnieść do współczesnych sensów pol. dotknać i motywującego go tknąć (por. Brücker 1970, s. 571, Boryś 2005, s. 633-634). Treść 'spróbować jedzenia/ picia’ zaświadczoną w zdaniach: Nawet nie dotknął drugiego dania i Od dwóch dni nie tknęła jedzenia można wywodzić od ogólniejszego sensu 'zbliżyć się do czegoś aż do zetknięcia, poruszyć, trącić' (Boryś 2005, s. 633). Zilustrowanie kolejnych znaczeń wymaga cofnięcia się do czasów staro- i średniopolskich, gdy dotknąć (się) i tykać się miały m.in. treść 'naruszyć stosunkiem płciowym' (SStp), tak samo, jak ich imienne formacje pochodne: dotknienie, (męskie) dotykanie 'contagium, coitus' (SStp).

Współcześnie, dzięki zróżnicowaniu łączliwości za pomocą przypadka fleksyjnego, użycia czasownika dotknąć są jednoznaczne ${ }^{29}$ - w połączeniu z dopełniaczem ma on znaczenie konkretne i odnosi się do kontaktu fizycznego: Jan dotkną Marii (palcem) ${ }^{30}$, zaś z biernikiem ma treść metaforyczną i wskazuje na to, że Jan czymś Marię uraził: Jan dotkną Marię (swoimi uwagami/ swoim zachowaniem) (zob. Pajdzińska 1996, s. 124-125). Relacyjność, do której można sprowadzić ostatni z sensów proponowanych przez Ibarretxe-Antuñano, tkwi głęboko w semantyce czasowników percepcyjnych dotykowych. Wydobywa ją zwłaszcza wyraz dotyczyć w konstrukcji (coś) dotyczy (kogoś, czegoś).

Różnice w znaczeniach sekundarnych między angielskimi, hiszpańskimi i baskijskimi czasownikami percepcji dotykowej są niewielkie i ograniczają się do odmian regionalnych języka Basków, co może wskazywać na ich wewnętrzny, izolowany rozwój (por. Ibarretxe-Antuñano bd, s. 242). Dużo istotniejsze jest to, że autorka poddaje analizie wyłącznie czasowniki czynnościowe, jak zresztą wielu językoznawców ${ }^{31}$, z tego powodu wśród sekundarnych sensów czasowników dotykowych nie wybijają się treści emocjonalne ${ }^{32}$. Wśród czynników

28 Niektóre z tych treści występują też w hebrajskim. Termińska pisze: „Obraz nieprzekraczalnej granicy usprawiedliwia i wiąże w całość z pozoru chaotyczny zbiór przypisywanych temu rdzeniowi znaczeń: 'dotykać, dochodzić, sięgać aż do, nadchodzić', a także, w dalszej kolejności: 'uczynić krzywdę, uderzyć, poruszyć'. Rdzeń ten jest również podstawą kilku interesujących idiomatyzmów: Bóg, ewentualnie ręka Boska może kogoś dotknąć i wówczas sprowadza nań chorobę, plagę, nieszczęście (...), Bóg może dotknąć czyjegoś serca i człowiek ten jest skruszony, poruszony, wzruszony (...), mężczyzna może dotknąć kobiety i jest to akt seksualny” (Termińska 2015, s. 87).

29 Inaczej niż w ang. zdaniu John touched Mary, które można interpretować dwojako: w odniesieniu do sfery fizycznej lub emocjonalnej, co wiąże się z pozycyjnością tego języka. Hiszpański i baskijski ekwiwalent tego wypowiedzenia mają wyłącznie konkretną treść.

30 Być może dlatego, że kontakt ma zawsze charakter „punktowy”, a więc partytywny. Recenzentowi dziękuję za tę cenną uwagę.

31 W książce Termińskiej także nie został uwzględniony hebr. rdzeń o biernej treści dotykowej.

32 Pojawiają się one, ale zależą od kontekstu i - poza angielskim - muszą być doprecyzowane przez odpowiednik słowa serce (por. Ibarretxe-Antuñano bd, s. 245 i 247). 
Wtórne znaczenia wyrazów percepcyjnych zmysłowych (zmysł powonienia, dotyku i smaku).. 531

charakterystycznych dla dotyku znajdują się: kontakt $(+)$, krótkotrwałość $(+)^{33}$ i graniczność (+), brak natomiast uwewnętrznienia (-) (Ibarretxe-Antuñano 1999b, s. 139-140), z czym przy biernym dotyku nie sposób się nie zgodzić. Tylko dla tego zmysłu charakterystyczny jest efekt (+), czyli zmiana wskutek percepcji (Ibarretxe-Antuñano 1999b, s. 150).

\subsection{Dotyk czynny a bierny}

W badaniu czasowników percepcyjnych dotykowych i ich znaczeń istotne jest uwzględnienie różnych rodzajów dotykania, na co zwraca uwagę Barbara Bartnicka, pisząc:

Dotykanie czegoś lub kogoś jest na ogół czynnością świadomą, wykonywaną przez podmiot osobowy (...). Należy zaznaczyć, że doznania zmysłowe percypowane za pomocą dotyku odbierane są zarówno przez agensa czynności (osobę dotykającą), jak i przez jej patiensa, jeśli jest nim inny człowiek (osoba dotykana). Wszelkie inne doznania zmysłowe są jednostkowe (...). Tylko w wypadku kontaktów dwu osób za pomocą dotyku wrażenia są odbierane przez obu uczestników kontaktu (Bartnicka 2007, s. 57-58).

Dotyk bierny nie jest zmysłem stricte percepcyjnym a czuciowym i trzeba go traktować autonomicznie, co podkreśla Ewa Klekot we Wstępie do eseju Juhaniego Pallasmy:

Dotyk to nie zmysł podboju lecz bezpieczeństwa. Natomiast ręka, która sięga, by pomacać, odwraca tę logikę i sprawia, że dotyk zaczyna działać w tym samym trybie co wzrok... (Klekot 2015, s. 12).

Biolodzy częściej niż przedstawiciele innych dziedzin nauki używają określenia czucie somatyczne, w obrębie którego wyróżniają czucie powierzchniowe (skórne) (a tu: czucie dotyku i czucie termiczne), czucie głębokie (proprioceptywne) i trzewne (Sadowski 2009, s. 162). Znaczenia czasownika czuć obejmują wszystkie te rodzaje percepcji.

W aktywnym dotykaniu podmiot (zazwyczaj) działa świadomie, inicjuje czynność (sięga po coś, dotyka czegoś, uderza w coś) i się rusza ${ }^{34}$, dotyk pasywny jest niezależny od woli perceptora, który pozostaje nieruchomy lub ruch jego ciała nie jest istotny (choć może on próbować uniknąć kontaktu). Przy aktywnym dotykaniu łatwiej jest przerwać kontakt niż przy odbieraniu (zbyt intensywnego)

33 Perceptorowi wystarcza nawet najkrótsze zetniknięcie z obiektem, by odebrać bodziec i przesłać impuls do mózgu.

34 W polszczyźnie kojarzone z dotykaniem są dłoń, ręka i ewentualnie palec, o czym świadczy konieczność dookreślenia innej części ciała (np. dotknąć językiem, łokciem) (por. Pajdzińska 1996, s. 124; Ładziak 2012). 
bodźca. W dotyku - tak jak w węchu - komórki nerwowe adaptują się do długotrwałego bodźca (dotyk ubrania, obuwia, kołdry, nacisk biżuterii, okularów, aparatu ortodontycznego itp.), którego po pewnym czasie perceptor nie rejestruje. Inaczej jest, gdy któraś z części odzieży uwiera lub jest uszyta z nieprzyjemnego materiału.

Dotyk czynny z biernym łączy odczuwanie temperatury, wilgotności, faktury i (ewentualne) wibracji obiektu, z którym podmiot się styka, ale już odczuwanie nacisku jest różne dla każdego typu. Zasadnicza różnica dotyczy odczuwania ciężaru i cechuje wyłącznie dotyk bierny - wskutek przekraczania granicy ciała podmiotu zmysł ten łączy się z propriocepcją. W tabeli 1. zebrano podobieństwa i różnice między czynnym dotykaniem a biernym dotykiem; część z czynników określam jako możliwe czy zależne od sytuacji, gdyż często kontekst decyduje o ich interpretacji.

Tabela 1. Podobieństwa i różnice między dotykiem czynnym a biernym

\begin{tabular}{|c|c|}
\hline Dotyk czynny & Dotyk bierny \\
\hline \multicolumn{2}{|c|}{$\begin{array}{l}\text { Odczuwanie temperatury, wilgotności, faktury i wibracji obiektu, nacisku związanego } \\
\text { z dotykaniem }\end{array}$} \\
\hline---- & Odczuwanie ciężaru na własnym ciele \\
\hline $\begin{array}{l}\text { Aktywne działanie, często związane } \\
\text { z ruchem części ciała }\end{array}$ & $\begin{array}{l}\text { Pasywny odbiór bodźca z zewnątrz, zwykle } \\
\text { niezwiązany z ruchem części ciała }\end{array}$ \\
\hline Raczej świadome i celowe działanie & Może być świadomy odbiór \\
\hline $\begin{array}{l}\text { W wypadku dyskomfortu można } \\
\text { przerwać kontakt }\end{array}$ & $\begin{array}{l}\text { W wypadku dyskomfortu nie zawsze można } \\
\text { przerwać kontakt }\end{array}$ \\
\hline $\begin{array}{l}\text { Wyraźne dochodzenie do prze- } \\
\text { strzennej granicy dotykanego } \\
\text { obiektu }\end{array}$ & $\begin{array}{l}\text { Wskutek zbyt silnego nacisku powierzchnia } \\
\text { skóry perceptora może zostać odkształcona lub } \\
\text { przerwana (w wypadku ranienia, ukłucia itp.) }\end{array}$ \\
\hline Zmiana odbierana w krótkim czasie & $\begin{array}{l}\text { Może to być zmiana odbierana w krótkim czasie } \\
\text { lub długotrwały dotyk, który jest traktowany jako } \\
\text { naturalny i prawie nierejestrowany }\end{array}$ \\
\hline
\end{tabular}

Zestawienie w tabeli 2. ukazuje, że niektóre komponenty znaczeniowe emocji ${ }^{35}$ można uzasadnić metaforyzacją charakterystycznych cech biernego dotyku, np. ciężar odczuwany w propriocepcji może - wskutek metafory - być traktowany jako wyobrażenie tego, co sprawia, że podmiot cierpi emocjonalnie, czuje się przytłoczony jakimś doświadczeniem. W tabeli 2 . zostały zebrane te cechy dotyku biernego, które są istotne w odniesieniu do emocji.

35 Przymuję za M. Johnsonem rozumienie emocji jako „pierwotnego sposobu pozostawania przez nas w kontakcie z naszym światem” czy, innymi słowy „procesami współdziałania między organizmem a środowiskiem" (Johnson 2015, s. 84 i 85). 
Wtórne znaczenia wyrazów percepcyjnych zmysłowych (zmysł powonienia, dotyku i smaku)... 533

Tabela 2. Wybrane komponenty znaczeniowe biernego dotyku a cechy emocji

\begin{tabular}{|l|l|}
\hline \multicolumn{1}{|c|}{ Dotyk bierny } & \multicolumn{1}{c|}{ Emocje } \\
\hline Odczuwanie ciężaru & Negatywne emocje to ciężar \\
\hline Brak wpływu na odbiór bodźca z zewnątrz & $\begin{array}{l}\text { Człowiek podlega emocjom, doświadcza } \\
\text { ich, ale nie może nimi kierować }\end{array}$ \\
\hline $\begin{array}{l}\text { Niemożność przerwania kontaktu przez } \\
\text { perceptora }\end{array}$ & $\begin{array}{l}\text { Niemożność zdystansowani się do emocji, } \\
\text { nawet gdy podmiot wie, że one mu szkodzą }\end{array}$ \\
\hline $\begin{array}{l}\text { Postrzeganie ciała/ powierzchni skóry } \\
\text { perceptora jako granicy }\end{array}$ & $\begin{array}{l}\text { Zewnętrzna przyczyna powoduje zmiany } \\
\text { w emocjach człowieka }\end{array}$ \\
\hline $\begin{array}{l}\text { Postępujące z czasem przyzwyczajanie się } \\
\text { perceptora do danego bodźca }\end{array}$ & $\begin{array}{l}\text { Długotrwałe pozostawanie pod wpływem } \\
\text { niektórych emocji sprawia, że mówi się } \\
\text { o nastrojach danego człowieka lub jego } \\
\text { usposobieniu }\end{array}$ \\
\hline
\end{tabular}

Różnica między oboma typami dotyku jest najwyrazistsza w wypadku ciężaru, który przy czynnym dotykaniu może być jedynie oszacowany, ale nie wpływa bezpośrednio na skórę perceptora ${ }^{36}$. Z tego powodu rozpatrzę szczegółowiej wtórne znaczenia zawierające ten komponent semantyczny. Ciężar konceptualizowany jako kamień umiejscawia się na sercu, piersi lub duszy podmiotu, gdyż tam - w naszej kulturze - są lokalizowane uczucia. Taki nacisk odbiera się jako nieporządany, nieprzyjemny, zbyt silny, a jednocześnie zazwyczaj pojawia się on niespodziewanie. Nie sposób się od niego zdystansować i uwolnić. W odniesieniu do emocji wyrażają to frazeologizmy: (komuś) jest/ zrobiło się ciężko na duszy/ na sercu (USJP) i (coś) ciąży (komuś) kamieniem/ jak kamień/ (coś) (komuś) kładzie się/ leży kamieniem na sercu/ (coś) uciska kamieniem sercel duszę (USJP) i kamień przygniata (komuś) serce (USJP) oraz związki mówiące o zmianie tego samopoczucia: kamień spadł (komuś) z serca, (komuś) ulżyło/ jest lizej na duszy, zdjać (komuś) kamień z serca, zrzucić kamień z serca, kamień spadł (komuś) z sercal z piersi.

Cechę graniczności potwierdzają zakorzenione w języku metafory mówiące o relacji między ludźmi: (ktoś) naciska na (kogoś), (ktoś) (kogoś) uraził, (ktoś) (kogoś) (czymś) zranił, (ktoś) dotkną (kogoś) do żywego, (ktoś) (komuś) zalazł za skórę. Długotrwałe pozostawanie pod wpływem bodźca dotykowego powodowuje, że perceptor się doń przyzwyczaja (najsilniej odbiera się zmianę bodźca lub jego natężenia), w zbliżony sposób człowiek reaguje na sytuację emocjonalną, w której się znajduje i która nań oddziałuje.

36 Oczywiście, że gdy podmiot pcha jakiś przedmiot, odczuwa jego ciężar, ale jest to inne doświadczenie niż wtedy, gdy dany przedmiot leży na ciele perceptora. 


\subsection{Dotyk a ogólnopercepcyjna treść czasownika}

Cechą angielskich i hiszpańskich czasowników percepcji dotykowej jest to, że wyrażają one także treści ogólnopercepcyjne, jednak inne języki ${ }^{37}$ nie pozwalają uznać jej za uniwersalną (por. Ibarretxe-Antuñano bd, s. 235-236 i 250), choć polskie czuć potwierdza tę zależność. Jeszcze w epoce prasłowiańskiej czasownik čüti odnosił się do ogólnozmysłowej i polisensorycznej percepcji, następnie uległ zawężeniu do konkretnych treści percepcyjnych, w polszczyźnie m.in. biernego dotyku, nie straciwszy jednak wartości ogólnej (por. Piotrowska 2017, s. 247-260; Piotrowska 2018). Taki kierunek zmian (ogólna percepcja $\rightarrow$ dotyk) znajduje uzasadnienie $\mathrm{w}$ analizach Viberga, ale stanowi tylko jeden $\mathrm{z}$ możliwych wariantów. $\mathrm{Z}$ ustaleń tego autora wynika, że tak samo prawdopodobne są kierunki: ogólna percepcja $\rightarrow$ słuch; ogólna percepcja $\rightarrow$ węch itp., które potwierdza jeden $\mathrm{z}$ sensów czuć w polszczyźnie ogólnej (w odniesieniu do węchu) lub w gwarach (do słuchu).

\subsection{Inne wrażenia czuciowe}

Warto zastanowić się jeszcze nad pomijanymi przy dotyku odczuciami somatycznymi, m.in. fizjologicznymi, zachodzącymi w ciele podmiotu i przezeń odczuwanymi, takimi jak głód, pragnienie, ból, senność, zmęczenie itp. Przedstawiciele nauk przyrodniczych opisują je odrębnie (por. Sadowski 2009), ale fakt, iż do mówienia o nich jest używany ten sam czasownik w analogicznych konstrukcjach składniowych, sprawia, że trzeba się zastanowić, czy nie świadczy to o odzwierciedlanej w języku naiwnej wiedzy o fizjologii (np. czuć ból w nodze, czuć ciepło na twarzy). Podobieństwa pozajęzykowe, które mogłyby to uzasadniać, to niezależność od woli perceptora i wzrastające ze stopniem natężenia bodźca zaangażowanie emocji podmiotu.

Innym typem bodźców są ruchy dziecka ${ }^{38}$ odczuwane przez ciężarne kobiety czy sytuacja operacji, w czasie której pacjent pozostaje świadomy, słyszy i czuje ${ }^{39}$, co się dzieje. $\mathrm{Z}$ tego, co mi wiadomo, nie zostały one poddane badaniom językowym, a materiał historyczny w tym wypadku nie jest pomocny,

${ }^{37}$ Ibarretxe-Antuñano ma wątpliwości co do języka rosyjskiego, ale nie podaje szczegółów. Z artykułu Galiny Ryliny porównującego składnię i semantykę ang. feel i ros. čuvstvovat' (ros. чувствовать) wynika jednakże, iż ten ostatni ma treści odnoszące się do zmysłów dotyku, węchu i smaku oraz ogólnopercepcyjny sens zmysłowy (Rylina 2013). Aby mówić o zależnościach między znaczeniem percepcyjnym dotykowym a ogólnozmysłowym czasowników w różnych językach, należy przeprowadzić szeroko zakrojone badania porównawcze i historyczne.

38 W zaawansowanej ciąży są one odczuwane nie tylko przez matkę, ale także widoczne na powierzchni brzucha.

39 Przykładowo, mimo że przy znieczuleniu zewnątrzoponowym operowany nie odczuwa bólu, to nawet w miejscu przeprowadzanego zabiegu odbiera bodźce dotykowe (poza temperaturą). 
gdyż rejestruje tylko pojedyncze cytaty świadczące o wykorzystywaniu w tych kontekstach czasownika $c z u c^{40}$. Ze względu na tabu językowe nie są także notowywane odczucia uczestników aktu seksualnego (por. Krawczyk-Tyrpa 2001, s. 127-146). W odniesieniu do dawnej polszczyzny można mówić jedynie o hipotezach, ale brak poświadczeń w tekstach nie oznacza, żeby ludzie na pewne, nawet stabuizowane, tematy ze sobą nie rozmawiali, co potwierdza materiał gwarowy (Krawczyk-Tyrpa 2001) i wiedza współczesnego użytkownika potocznej polszczyzny.

\section{Smak}

Językoznawcy są zgodni, że indywidualny charakter odczuć smakowych uzależniony od wieku, zdrowia i przyzwyczajeń jedzącego/ pijącego wpływa na jakość metafor i przesuwanie ich do upodobań jednostkowych - (nie)lubienia czegoś (por. Sweetser 1990; Ibarretxe 1996, s. 631). To nacechowanie zrealizowało się we wtórnej treści czasowników smakowych omawianych przez Ibarretxe-Antuñano: 'sprawiać przyjemność, lubić', bardziej wyraziste jest jednak w rzeczownikach nazywających smak w angielskim (taste), hiszpańskim (sabor i gusto) oraz baskijskim (zapore i gustu - obydwa są zapożyczeniami z hiszp.) (Ibarretxe-Antuñano 1999b, s. 86, 103-104). Podobieństwa znaczeniowe w odniesieniu do upodobań podmiotu i sfery estetyki - zwłaszcza między pol. gustem, hiszp. gusto i bask. gustu - można objaśniać ich wspólnym łacińskim pochodzeniem, a w baskijskim faktem, iż bezpośrednim źródłem pożyczki był hiszpański. Sensy te występują jednak również w niepowiązanych już etymologicznie wyrazach smak i ang. taste. Ibarretxe-Antuñano uogólnia je w wypadku nominów do (nie)lubienia czegoś oraz opinii na temat estetyki, właściwości intelektualnych i zachowań międzyludzkich (Ibarretxe-Antuñano 1999b, s. 88).

W polskiej literaturze dotyczącej określeń związanych ze smakiem poczesne miejsce zajmują prace Anny Pajdzińskiej, Renaty Bronikowskiej i Barbary Mitrengi. Pierwsza z nich dostrzega ten sam kierunek przesunięć semantycznych, co opisany powyżej, i - według niej - przeobrażenia te dotyczą wyrazów stanowiących konkretyzację sensu 'cecha jedzenia lub napoju, działająca na zmysł smaku'. Są widoczne w wartościowanej pozytywnie słodyczy (i przymiotniku

40 Znikoma liczba takich poświadczeń wynika z faktu, iż stan odmienny kobiety (ciąża, poród i połóg, okres i poronienie) pozostawał kulturowo i językowo stabuizowany (zob. Krawczyk-Tyrpa 2001, s. 15-18; 112-119; 146-149; 151-166), więc tematyka ta była przemilczana (za: Krawczyk-Tyrpa 2001, s. 27-29). Ponadto kobiety częściej niż mężczyźni były niepiśmienne, a ci ostatni - zielarze, lekarze czy księża - poprzestawali na stwierdzeniu faktów. 
słodki $)^{41}$ stanowiącej wtórnie określenia czegoś łagodnego, przyjemnego, delikatnego, czułego (np. słodkie spojrzenie, słodycz charakteru, słodziak - o dziecku, słodkie sny) i w goryczy, która uwydatnia silne, nieprzyjemne i wartościowane negatywnie przez podmiot doświadczenia (np. rozgoryczenie, zgorzkniałość, gorzki los, słowa pełne goryczy, mówić/ myśleć o czymś z gorycza, wychylić kielich/ czare goryczy, gorzka prawda, gorzkie przebudzenie, gorzka wiedza).

Renata Bronikowska wśród wtórnych treści określeń wiązanych ze smakiem wydziela uczucia i ich objawy (np. słodki/ gorzki (u)śmiech, gorzkie łzy, por. Bronikowska 2002, s. 51), a także konteksty przywołujące przyjemne doświadczenia - sen i próżnowanie (np. słodka drzemka), erotykę (np. słodkie pieszczoty), chociaż mogą się one pojawiać w kontekstach wskazujących na oderwanie podmiotu od rzeczywistości (np. słodkie wspomnienia) i jego złudzenia co do niej (np. słodkie kłamstwa) wynikające z niewiedzy o sytuacjach dla podmiotu nieprzyjemnych (np. słodka niewiedza, słodkie marzenia). Takie użycia mogą nabierać odcienia pobłażliwego lub negatywnego, gdy uwypuklają doznania przyjemne dla podmiotu, ale niemające pokrycia w rzeczywistości (por. Bronikowska 2002, s. 53-55).

Wybranej leksyce smakowej poświęciła monografię Barbara Mitrenga, która scharakteryzowała m.in. dawne określenia nazywające ten zmysł (ukuszenie ${ }^{42}$ ) i współczesne, będące dawnymi zapożyczeniami ${ }^{43}$ słowa, a także podstawowe właściwości pokarmów. Wśród analizowanej leksyki przeważają formacje imienne (Mitrenga 2014, s. 15), a sama praca uwzględnia szerokie tło historyczne i kulturowe. Autorka podkreśla, że smak potraw jest uzależniony od ich konsystencji, temperatury, zapachu i wyglądu, a także - tak samo jak jego wartościowanie - od historii i wzorca kulturowego danego etnosu (por. Mitrenga 2014, s. 44).

Wieloznaczność wyrazu smak, będącego XV-wiecznym zapożyczeniem ze śr.-wys.-niem. smacl smacke 'smak, zmysł smaku; smak czegoś, posmak', utrzymywała się i poszerzała w polszczyźnie, co zaświadczają źródła średniopolskie (więcej zob. Mitrenga 2014, s. 66-75), obecnie jest nazwą zmysłu i 'zdolności rozpoznawania pewnych właściwości przyjmowanych pokarmów’, ponadto - wskutek metonimii - 'właściwości rzeczy, najczęściej jadalnych, działającej na zmysł

41 Rozważania na temat wyrazów z rodziny rzeczownika sól nie odnoszą się bezpośrednio do zagadnień poruszanych w artykule (por. Mitrenga 2014, s. 87-88; 106 i n.).

42 Ten dewerbalny rzeczownik był nazwą zmysłu i czynności od XVI do połowy XIX wieku (por. Mitrenga 2014, s. 55 i n.). Do dzisiaj wyrazy z rodziny kusić funkcjonują w odniesieniu do smaku w związkach frazeologicznych (np. kuszący smak, słodka pokusa, skusić się na coś słodkiego, więcej przykładów zob. Mitrenga 2014, s. 65-66).

43 Inne wyrazy z pola znaczeniowego smaku to również pożyczki z niemieckiego: kosztować $\leftarrow$ st.-wys.-niem. kosten, próbować $\leftarrow$ niem. Probe, a także jeszcze psł. kusić $\leftarrow$ goc. kausjan (zob. Mitrenga 2014, s. 58-61), które stało się wyrazem podstawowym czasownika ukusić (por. Boryś 2005, s. 276). 
smaku (często właściwości sprawiającej przyjemne wrażenie)' oraz 'chęci do jedzenia lub picia, apetytu, przyjemności, które ktoś odczuwa podczas jedzenia lub picia, czasem palenia'. Każda z tych treści podlega metaforycznym rozszerzeniom. Uzasadnione biologicznie (np. Spitzer 2018) jest to, że w tych samych kategoriach co własności smakowe są ujmowane rzeczy powodujące psychiczne doznania człowieka (przykłady zob. Pajdzińska 1996, s. 125). Ostatnie ze znaczeń stało się podstawą sensu 'upodobanie, pociąg do czegoś, chęć na coś', realizującego się m.in. w związkach: (coś) jest (komuś) nie w smak i obejść się/ obyć się smakiem. Tak rozumiany smak odnosi się do sfery estetycznej i jest wyrazem bliskoznacznym gustu. Treść ta mogła się wykształcić zarówno na rodzimym gruncie, jak i stanowić pożyczkę semantyczną z łaciny lub niemieckiego, ku czemu skłania się Mitrenga.

Niestety, żadna z autorek nie przywołuje innych wyrazów łączących się ze smakiem: pominięte zostały zarówno czasowniki czuć, uczuć, jak i ich wyrazy pokrewne mające związek z odczuciami smakowymi, mimo że pojawiają się w przytaczanych cytatach ${ }^{44}$.

Analizy Ibarretxe-Antuñano ukazują, że mało jest wspólnych dla angielskiego, hiszpańskiego i baskijskiego wtórnych treści czasowników percepcyjnych smakowych (zob. Aneks, tabela 3.). Odnoszą się one do uczuć (pozytywnych i negatywnych), doświadczania czegoś, a w hiszpańskim także 'wiedzy'. Dwa ostatnie sekundarne sensy smakowe nie są charakterystyczne dla języka polskiego, przywołuje je jednak z języków romańskich Sweetser (Sweetser 1990, s. 37), a Termińska, analizując hebr. rdzeń T(et)'M o pierwotnym znaczeniu percepcyjnym smakowym, łączy go z predyspozycjami psychicznymi: rozsądkiem, umiarem, rozwagą, doświadczeniem i roztropnością (por. Termińska 2015, s. 83). Ibarretxe-Antuñano wśród czynników konstytutywnych dla smaku umieszcza: kontakt (+), uwewnętrznienie (+), dobrowolność (+) i krótkotrwałość (+) oraz ocenianie (wartość hedonistyczną) (+) (Ibarretxe-Antuñano 1999b, s. 142 i 151).

\section{Podsumowanie}

Wtórne znaczenia czasowników percepcyjnych węchowych, dotykowych i smakowych przywołane w artykule nie wyczerpują możliwych sensów tej

${ }_{44} \mathrm{~Np}$. „Czemu język ma w sobie pory, to jest dziurkowany jest wszytek a rzadki, więcej niźli insze mięso? Odpowiedź: Jedna przyczyna tego, aby smak pokarmu tym snadniej przechodził do onego członka, w którym jest czujność ukuszenia” (Glaber 1535 [1893], s. 29) i „Czemu ślina człowiecza żadnego smaku nie ma? Odpowiedź: Bo gdyby ona miała w sobie jaki smak własny, tedy by język żadnego inszego smaku nie uczuł, gdyż język pomocą śliny czuje ukuszając" (Glaber 1535 [1893], s. 31). 
leksyki. Gdyby szczegółowo rozpatrywać jakiś polisem w jego ewolucji historycznej lub omówić wyrazy z jednej rodziny słowotwórczej, okazałoby się, że należy uwzględnić wiele innych sensów sekundarnych. Tu skupiłam się na przeglądzie uniwersalnych i międzyjęzykowych (ang. cross-linguistic) (Ibarretxe 1996, s. 642) znaczeń czasowników prymarnie percepcyjnych, chociaż niektóre wspomniane przekształcenia ograniczają się do jednego języka. Zestawienie polszczyzny z angielskim, hiszpańskim i baskijskim miało na celu ukazanie wspólnych tendencji semantycznych dostrzeżonych w słownictwie percepcyjnym $\mathrm{w}$ niespokrewnionych ze sobą i niepozostających w jednym kręgu kulturowym językach, chociaż różnią się one niektórymi wtórnymi sensami. Okazuje się jednak, że wtórne treści dostrzeżone przez Ibarretxe-Antuñano tylko w baskijskich czasownikach percepcyjnych występują także w polskiej leksyce zmysłowej, co można uzasadnić właściwym człowiekowi sposobem doświadczania świata, niezależnym od języka i kultury. Zbieżności semantyczne ${ }^{45}$ można ponadto objaśniać wspólnym pochodzeniem języków (por. Ibarretxe-Antuñano 1998, s. 201; Kurath 1921; Buck 1949), ich przynależnością do ligi językowej i wspólnotą kulturową. Ważne przy tym jest, by uwzględniać - w miarę możliwości - historię danego języka i analizowanej leksyki, gdyż można wtedy dostrzec różnego rodzaju zmiany, np. ewoluującą w czasie przynależność danego wyrazu do któregoś ze zmysłów, jak działo się z czasownikiem czuć, czy tzw. przesunięcia (ang. shifts) w sposobie hierarchizowania zmysłów ${ }^{46}$ (por. Piotrowska 2018).

Irraide Ibarretxe-Antuñano proponuje, by metaforę ROZUMIENIE TO WIDZENIE zastąpić jej hiperonimem: ROZUMIENIE TO PERCEPCJA (UNDERSTANDING IS PERCEPTION), gdyż w tym ujęciu mieści się każdy zmysł (por. Ibarretxe-Antuñano 2002, s. 29-30). Hipoteza ta jest efektem badań Ibarretxe-Antuñano i prób uogólnienia zmian znaczeniowych dostrzeżonych $\mathrm{w}$ verbach percepcyjnych odnoszących się do poszczególnych zmysłów, lecz także łączących doznania odbierane jednocześnie za pomocą kilku zmysłów, co w polszczyźnie najlepiej ukazuje wieloznaczny czuć. W innych dziedzinach nauki zbliżone spostrzeżenia pojawiły się również na przełomie XX i XXI wieku. Przykładowo architekt Juhani Pallasmaa w eseju Oczy skóry za filozofem M. Merleau-Pontym podkreśla symultaniczność percepcji i interakcyjności wszystkich zmysłów: człowiek postrzega świat całym sobą (por. Pallasmaa 2012, s. 28). Wynika $\mathrm{z}$ tego, że należałoby nie tylko omawiać łącznie wtórne sensy percepcyjne

45 W wypadku różnic znaczeniowych Ibarretxe-Antuñano podkreśla stopniowalną polisemię i wpływ kontekstu charakterystyczny dla danego języka (Ibarretxe-Antuñano 1999b, s. 212-214).

46 Dodać należy, że trzeba też uwzglednić wiele innych czynników - kulturowych, geograficznych, historycznych oraz językowych, gdyż czasowniki percepcyjne mogą różnić się od siebie zakresem znaczeniowym w odniesieniu do samej percepcji (np. Viberg 1984). 
motywowane przez tzw. niższe zmysły, lecz scharakteryzować także szczegółowo wtórne znaczenia czasownika $c z u c ́$ - w jego historycznej ewolucji, ale jest to już pomysł na inny artykuł.

\section{Aneks}

Tabela 3. MIND-AS-BODY conceptual metaphor in English, Basque and Spanish perception verbs

\begin{tabular}{|l|l|l|l|l|l|}
\hline \multicolumn{2}{|c|}{$\begin{array}{c}\text { EETAPHORS IN THE PERCEPTUAL DOMAIN } \\
\text { English }\end{array}$} & \multicolumn{3}{c}{ LANGUAGES } \\
\hline & Basque & Spanish & \\
\hline & Affecting is touching & $\sqrt{ }$ & $\sqrt{ }$ & $\sqrt{ }$ \\
\hline & Dealing with is touching & $\sqrt{ }$ & $\sqrt{ }$ & $\sqrt{ }$ \\
\hline & Considering is touching & & $\sqrt{ }$ & \\
\hline & Persuading is touching & & $\sqrt{ }$ & \\
\hline \multirow{5}{*}{ TOUCH } & Suspecting is smelling & $\sqrt{ }$ & $\sqrt{ }$ \\
\hline & Sensing/guessing is smelling & $\sqrt{ }$ & $\sqrt{ }$ & $\sqrt{ }$ \\
\hline & Investigating is smelling/sniffing around & $\sqrt{ }$ & $\sqrt{ }$ & $\sqrt{ }$ \\
\hline & Showing contempt is sniffing & & $\sqrt{ }$ & \\
\hline & Corrupting is smelling & & $\sqrt{ }$ & \\
\hline & Not to get wind of something is not to smell & & $\sqrt{ }$ & \\
\hline & Prophesying is smelling & & $\sqrt{ }$ & \\
\hline \multirow{5}{*}{ TASTE } & Experiencing something is tasting & $\sqrt{ }$ & $\sqrt{ }$ & $\sqrt{ }$ \\
\hline & $\begin{array}{l}\text { Producing a feeling is tasting } \\
\text { (enjoying/disliking) }\end{array}$ & $\sqrt{ }$ & $(\sqrt{ })$ & $\sqrt{ }$ \\
\hline & Knowing is tasting & & & $\sqrt{ }$ \\
\hline
\end{tabular}

(Źródło: Ibarretxe-Antuñano 2002, s. 114).

\section{Bibliografia}

Bańkowski, A. (2000). Etymologiczny słownik języka polskiego, t. 1-2. Warszawa.

Bartnicka, B. (2007). Świat doznań zmysłowych (węch, smak, dotyk). Słownictwo pism Stefana Żeromskiego, t. 8. Kraków: Universitas.

Bronikowska, R. (2002). Nazwy cech percypowanych zmysłem smaku jako określenia uczuć, Poradnik Językowy, 6, 43-58. 
Boryś, W. (2005). Słownik etymologiczny języka polskiego. Kraków.

Brückner, A. (1970). Słownik etymologiczny języka polskiego. Warszawa.

Buck, C.D. (1949). A Dictionary of Selected Synonims in the Principal Indo-European Languges. Chicago: The University of Chicago Press Books.

Bugajski, M. (2004). Jak pachnie rezeda? Lingwistyczne studium zapachów. Wrocław.

Buttlerowa, D. (1978). Rozwój semantyczny wyrazów polskich. Warszawa.

Cejmer, A. (2014). O jednostkach trójargumentowych z ciągiem czuć, Linguistica Copernicana, 11, 69-86.

Cejmer, A. (2014). Kilka uwag na temat jednostek języka o kształcie [ktoś] czuje [coś]. Poradnik Językowy, 6, 52-63.

Chojnacka-Kuraś, M. (2016). Semantyka bólu we współczesnej polszczyźnie. Warszawa: Wydział Polonistyki UW.

Chojak, J. (2007). O „językowym obrazie” percepcji zmysłowej, Prace Filologiczne, 53, $79-86$.

Czerniawska, J.M., Czerniawska, E. (2005). Pamięć węchowa: fascynująca nieznajoma. W: E. Czerniawska (red.), Pamięć. Zjawiska zwykłe i niezwykłe (90-109). Warszawa: WSiP.

Danielewiczowa, M. (2000a). Co wie, a czego nie wie podmiot polskich predykatów „być pewnym, że_” oraz „być przekonanym, że_”. W: R. Grzegorczykowa, K. Waszakowa (red.), Studia z semantyki porównawczej. Nazwy barw, nazwy wymiarów, predykaty mentalne, cz. I (275-288). Warszawa: WUW.

Danielewiczowa, M. (2000b). Główne problemy opisu i podziału czasownikowych predykatów mentalnych. W: R. Grzegorczykowa, K. Waszakowa (red.), Studia z semantyki porównawczej. Nazwy barw, nazwy wymiarów, predykaty mentalne, cz. I (227-248). Warszawa: WUW.

Danielewiczowa, M. (1998). O szczególnych właściwościach 1 os. lp pewnych predykatów mentalnych, Prace Filologiczne, 43, 119-129.

Danielewiczowa, M. (2002). Wiedza i niewiedza. Studium polskich czasowników epistemicznych. Warszawa: Katedra Lingwistyki Formalnej UW.

Elektroniczny słownik języka polskiego XVII i 1 połowy XVIII wieku, (red.) Włodzimierz Gruszczyński. PAN, https:// sxvii.pl/. (E SXVII-XVIII).

Glaber, A. (1535 [1893]). Gadki o składności członków człowieczych.... Kraków.

Grzegorczykowa, R. (1995). Wpływ etymologii na współczesne rozumienie znaczeń wyrazów. W: F. Sławski, H. Mieczkowska (red.), Studia z językoznawstwa słowiańskiego (59-62). Kraków: Prace Instytutu Filologii Słowiańskiej UJ, nr 14.

Grzegorczykowa, R. (2012). Określenia percepcji węchowej w języku polskim. W: Świat widziany poprzez słowa: szkice z semantyki leksykalnej. Warszawa, s. 160-168.

Grzesiak, R. (1983). Semantyka i składnia czasowników percepcji zmysłowej. Wrocław: Zakład Narodowy im. Ossolińskich. 
Wtórne znaczenia wyrazów percepcyjnych zmysłowych (zmysł powonienia, dotyku i smaku).. 541

Ibarretxe, I. (1996). Semantic extensions in the sense of smell. W: ASJU, XXX-2, s. 631-643. http://www.ehu.eus/ojs/index.php/ASJU/article/download/8665/7833 [data dostępu 15.12.2018]

Ibarretxe-Antuñano, I. (1998). Predictable vs. unpredictable polysemy, LACUS Forum 25, S.J. Hwang, A. Lommel (eds.), s. 201-211. https://pdfs.semanticscholar.org/9c29/d0bae9772d6a1712b9c3c88ad50fc23eff17.pdf [data dostępu 28.02.2018]

Ibarretxe-Antuñano, I. (1999a). Metaphorical Mappings in the Sense of Smell, Metaphor in Cognitive Linguistics. R.W. Jr. Gibbs, J. Steen. Amsterdam and Philadelphia, s. 29-45.

https://Ibarretxe-Gibbs-Steen-99-metaphorical-mappings-in-the-sense-of-smell-1999pdf [data dostępu 28.02.2018]

Ibarretxe-Antuñano, I. (1999b). Polysemy and Metaphor in Perception Verbs: a Cross-linguistic Study (Thesis submitted for the Degree of Doctor in Philosophy. University of Edinburgh, unpublished) http://www.academia.edu/download/4856287/ibarretxe-phd-thesis-99.pdf [data dostępu 28.02.2018]

Ibarretxe-Antuñano, I. (2008). Vision Methaphors for the Intellect: Are they Really Cross-Linguistic?. Atlantis. Journal of the Association of Anglo-Ameriacan Studies, 30.1, s. 15-33.

https://s3.amazonaws.com/academia.edu.documents/4951063/2008ibarretxe-antunnano.pdf?AWSAccessKeyId=AKIAIWOWYYGZ2Y53UL3A\&Expires $=1519820684 \&$ Si gnature $=$ rDveUSvLfPRyF07Ur\%2BqVCQaNUt8\%3D\&response-content-dispositio$\mathrm{n}=$ inline\%3B\%20filename\%3D2008._Vision_Metaphors_for_the_Intellect.pdf [data dostępu 28.02.2018]

Ibarretxe-Antuñano, I. (bez daty [bd]). Cross-linguistic Polysemy in Tacticle Verbs, Cognitive Linguistics Investigations across Languages, Fields, and Philosophical Boundaries, J. Luchenbroers (ed.). Amsterdam, s. 235-253.

https://www.researchgate.net/profile/Iraide_Ibarretxe-Antunano/publication/300834111_11_ Cross-linguistic_polysemy_in_tactile_verbs/links/577ea26008ae9485a4368817.pdf [data dostępu 28.02.2018]

Ibarretxe-Antuñano, I. (2002). Mind-as-body as cross-linguistic conceptual Metaphor, Miscelánea. A Journal of English and American Studies, 25, s. 93-119.

https://www.researchgate.net/profile/Iraide_Ibarretxe-Antunano/publication/272507067_MINDAS-BODY_as_a_Cross-linguistic_Conceptual_Metaphor/links/54e795800cf2f7aa4d4dba03. pdf [data dostępu 28.02.2018]

Johnson, M. (2015). Znaczenie ciała. Estetyka rozumienia ludzkiego. Łódź: Wydawnictwo Uniwersytetu Łódzkiego.

Judycka, I. (1963). Synestezja w rozwoju znaczeniowym wyrazów, Prace Filologiczne, 18, 59-78.

Kaczmarek, B.L.J. (2010). Sensoryczne uwarunkowania języka. W: A. Pajdzińska, R. Tokarski (red.), Relatywizm w języku i kulturze (381-392). Lublin: Wydawnictwo Uniwersytetu Marii Curie-Skłodowskiej. 
Karłowicz, J. (1900-1911). Słownik gwar polskich, t. I-VI. Kraków.

Klekot, E. (2015). Przestrzenność rzeczy myślacej [Przedmowa]. W: J. Pallasmaa, Myślaca dłoń. Kraków, s. 7-14.

Kövecses, Z. (2001). Metaphor. A practical introduction. New York.

Kranowitz, C.S. (2012). Nie-zgrane dziecko. Zaburzenia przetwarzania sensorycznego - diagnoza i postępowanie, (przeł.) A. Sawicka-Chrapkowicz. Gdańsk: Harmonia.

Kranowitz, C.S. (2015). Nie-zgrane dziecko w świecie gier i zabaw. Zajęcia dla dzieci z zaburzeniami przetwarzania sensorycznego, (przeł.) A. Sawicka-Chrapkowicz. Gdańsk: Harmonia.

Kucała, M. (1957). Porównawczy słownik trzech wsi małopolskich. Wrocław: Zakład im. Ossolińskich.

Kurath, H. (1921). The Semantic Sourcess of the Words for the Emotions in Sanskrit, Greek, Latin, and the Germanic Languages. Menasha, Wisconsin.

Lakoff, G., Johnson, M. (1980). Metafory w naszym życiu, (tłum.) T.P. Krzeszowski. Warszawa: Aletheia.

Ładziak, E. (2012). Świat zamknięty w dłoni: ból i przyjemność jako podstawowe konotacje wybranych czasowników opisujących poznanie przez zmysł dotyku, Linguarium Silva, 1, 109-122.

Merleau-Ponty, M. (1996). Widzialne i niewidzialne, wstęp i opracowanie J. Migasiński. Warszawa: Aletheia.

Mitrenga, B. (2014). Zmysł smaku. Studium leksykalno-semantyczne. Katowice: Wydawnictwo Uniwersytetu Śląskiego.

Ogólnosłowiański atlas językowy. Seria leksykalno-słowotwórcza. Człowiek, 2009, (red.) J. Siatkowski, J. Waniakowa, t. 9. Kraków (wersja elektroniczna) (OLA).

Pajdzińska, A. (1996). Wrażenia zmysłowe jako podstawa metafor językowych, Etnolingwistyka, 8, 113-130.

Pallasmaa, J. (2012). Oczy skóry. Architektura i zmysty, (przeł.) M. Choptiany. Kraków: Fundacja Instytut Architektury.

Piotrowska, A.E. (2017). Kształtowanie się znaczeń czasownika czuć i jego derywatów werbalnych w dobie staropolskiej, Prace Filologiczne, 71, 247-260.

Piotrowska, A.E. (2018). Hierarchia zmysłów w języku a sensy pie. rdzenia * $(s) k e u$ realizującego się m.in. w czasowniku czuć. W: B. Pędzich, M. Wanot-Miśtura, D. Zdunkiewicz-Jedynak (red.), Tyle się we mnie słów zebrało... Szkice o języku i tekstach (441-458). Warszawa: Dom Wydawniczy Elipsa.

Pisarkowa, K. (1972). Szkic pola semantycznego zapachów w polszczyźnie, Język Polski, 52, z. 5, 330-339.

Rylina, G. (2013). Contrastive study of a perception verb in English and Russian: feel vs čuvstvovat', Ghent University, Msc Thesis. https:/lib.ugent.be/fulltxt/ RUG01/002/060/500/RUG01-002060500_2013_0001_AC.pdf [data dostępu: 15.12.2018] 
Wtórne znaczenia wyrazów percepcyjnych zmysłowych (zmysł powonienia, dotyku i smaku).. 543

Sadowski, B. (2009). Biologiczne mechanizmy zachowania się ludzi i zwierząt. Warszawa: Wydawnictwo Naukowe PWN.

Sławski, F. (1952-1975). Słownik etymologiczny języka polskiego, t. 1-5 (A-Łż). Kraków.

Słownik gwar polskich PAN. (1994-1998). (red.) J. Reichan, t. V. Kraków.

Słownik polszczyzny XVI wieku. (1966 i n.). kom. red. S. Bąk et al., t.1-4, (red.) M.R. Mayenowa, Warszawa. (SXVI).

Spitzer, M. (2018). Dopamina i sernik. Warszawa: Wydawnictwo Naukowe PWN.

Sweetser, E. (1990). From etymology to pragmatics. Methaphorical and cultural aspects of semantics structure. Cambridge: Cambridge University Press.

Termińska, K. (2015). Studia z hebajszczyzny biblijnej. Niedoczytanie moje. Katowice: Wydawnictwo Uniwersytetu Śląskiego.

Uniwersalny słownik języka polskiego. (2003). (red.) S. Dubisz, t. 1-6, Warszawa. (USJP)

Viberg, Å. (1984). The verbs of perception: a typological study. Linguistics 21, 1, 123-162.

Wierzbicka, A. (2006). Semantyka. Jednostki elementarne i uniwersalne, (przeł.) A. Głaz, K. Korżyk, R. Tokarski. Lublin: Wydawnictwo Uniwersytetu Marii Curie-Skłodowskiej.

\section{Streszczenie}

W artykule zajęto się wybranymi wtórnymi znaczeniami czasowników percepcyjnych: dotykowych, smakowych i węchowych w różnych językach, przede wszystkim indoeuropejskich; dużo przykładów pochodzi z polszczyzny. Zasadnicza większość omawianych sensów jest wspólna niezależnie od pochodzenia języka i związków geograficznych czy kulturowych między etnosami, co może świadczyć o ich uniwersalności i związku z biologią i sposobem postrzegania świata za pomocą danego zmysłu. Do takich wniosków uprawniają związki między językami Aborygenów, Papuasów, Basków, Polaków, Brytyjczyków czy Hiszpanów. 